\author{
배합사료의 자유 및 제한 급여가 거세한우의 성장단계별 증체, \\ 사료섭취량 및 혈중 대사물질에 미치는 영향 \\ 권응기· 홍성구·성환후·윤상기 · 박병기 · 조영무 · 조원모· 장선식 · 신기준 · 백봉현 \\ 농촌진흥청 축산연구소
}

\title{
Effects of Ad libitum and Restricted Feeding of Concentrates on Body Weight Gain, Feed Intake and Blood Metabolites of Hanwoo Steers at Various Growth Stages
}

E. G. Kwon, S. K. Hong, H. H. Seong, S. G. Yun, B. K. Park, Y. M. Cho, W. M. Cho,

S. S. Chang, K. J. Shin and B. H. Paek

National Livestock Research Institute, R.D.A.

\begin{abstract}
Two hundred fifty eight Hanwoo steers were used in a completely randomized design experiment to determine the effects of ad libitum or restricted feeding of concentrates on body weight (BW) gain, feed intake, blood metabolites and hematological parameters. Steers were assigned at 6 months of age to feeding groups of ad libitum (T1) or restricted (T2) by 18 months of age. Steers in both groups were fed ad libitum from 19 months of age. The restrictive feeding levels were $1.2 \sim 1.5 \%$ of BW for the growing period and $1.7 \sim 1.8 \%$ of $\mathrm{BW}$ for the early fattening period. Average daily gains were significantly higher in $\mathrm{T} 1$ than in $\mathrm{T} 2$ from 10 to 14 months of age, but were significantly higher in $\mathrm{T} 2$ than in $\mathrm{T} 1$ from 20 to 24 months of age $(\mathrm{p}<0.05)$. Total dry matter intake (DMI) was higher in T1 than in T2 at 10,12 and 16 months of age $(\mathrm{p}<0.05)$. Total DMI of $\mathrm{T} 2$ was higher than that of $\mathrm{T} 1$ at 22 months of age $(\mathrm{p}<0.05)$. Feed conversions were significantly lower in T2 than in T1 from 20 to 30 months of age $(\mathrm{p}<0.05)$. Blood albumin concentrations were significantly higher in $\mathrm{T} 2$ than in $\mathrm{T} 1$ at $12,14,16$ and 18 months of age. Blood triglyceride concentrations were significantly higher in $\mathrm{T} 1$ than in $\mathrm{T} 2$ at 14 and 16 months of age $(\mathrm{p}<0.05)$. Blood inorganic phosphorus concentrations were significantly higher in $\mathrm{T} 2$ compared with $\mathrm{T} 1$ at $8,10,16$ and 22 months of age $(\mathrm{p}<0.05)$. Mean corpuscular volume and mean corpuscular hemoglobin were significantly lower in $\mathrm{T} 2$ than in $\mathrm{T} 1$ from 8 to 12 months of age $(\mathrm{p}<0.05)$, but those were significantly higher in $\mathrm{T} 2$ than $\mathrm{T} 1$ from 10 months to 12 months of age $(\mathrm{p}<0.05)$. Present results may indicate that the restricted feeding for the growing period does not show adverse effects on body weight gain with better feed conversion for the following late fattening period.
\end{abstract}

(Key words : Hanwoo steers, Ad libitum, Restricted, Feed conversion, Blood metabolites)

I. 서 론 비육기간의 연장(Dolezal 등, 1982)은 육량보다 육질 우선 위주로 소도체등급판정제도(농림부, 고품질 쇠고기를 생산하기 위한 대표적인 사 2004)가 전환됨에 따라 전업농가를 중심으로 양기술인 거세(조 등, 1992; Ting 등, 2003)와 급속히 확산되고 있고, 비육기 사료급여 방법

Corresponding author: E. G. Kwon, National Livestock Research Institute, Chahang-Ri, Doam-Myon, PyeongchangGun, Gangwon-Do, 232-952, Korea. Tel: 033-330-0612, E-mail: kug2237@rda.go.kr 
(배합사료 제한 혹은 자유급여)도 산육능력, 사 료효율 및 경제성에 영향을 미치는 중요한 요 인이므로(Andersen과 Ingvartsen, 1984; Hermesmeyer 등, 2002), 거세와 비육기간 연장에 따른 생산비를 절감시키기 위해서는 비육단계별로 사료급여량을 효율적으로 조절(자유급여, 제한 급여 또는 자유급여와 제한급여의 병행)해야 할 필요성이 있다.

거세우에서 일정기간 배합사료의 제한급여는 건물섭취량 감소로 일당증체량을 감소시키는 단점이 있지만(Loerch, 1990; Hermesmeyer 등, 2002), 건물 및 유기물 소화율(Murphy 등, 1994b) 과 영양소의 이용성(Hermesmeyer 등, 2000)을 개선하여 사료효율(Hicks 등, 1990)이 유의적으 로 향상될 뿐만 아니라 사료비를 포함한 생산 비용(Loerch와 Fluharty, 1998)도 줄일 수 있다. 또한 육성기 동안 배합사료 제한급여 후 비육 기에 사료 급여의 제한을 해제하게 되면 보상 성장을 통해 육성기의 일시적인 증체량 저하가 해소될 수 있다(Loerch, 1990).

한편, 혈중 대사물질과 호르몬 및 사육환경 조건간에는 복잡한 상호작용이 존재하는데 (Hornick 등, 1998), 특히 비육우에서 영양소 섭 취량의 과부족으로 인해 성장률의 변화가 초래 될 수도 있고, 이러한 영양소의 수급 불균형으 로 인해 혈중 대사물질과 체성장에 관여하는 호르몬의 농도가 변할 수도 있다(Hayden 등, 1993). 그러나 최근까지도 거세, 비육기간 및 사료의 제한급여 등에 관한 대부분의 사양실험 들이 발육, 사료효율 및 도체특성을 위주로 연 구가 진행되어 왔기 때문에 이들 요인에 따른 비육우의 체내 영양소 대사 및 생리적인 상태 를 직접적으로 반영하는 산육생리 관련 혈중 대사물질들에 대한 연구가 상대적으로 부족한 실정이다.

따라서 본 연구는 육성기 및 비육전기 동안 의 배합사료 자유급여와 제한급여가 거세한우 의 성장단계별 증체 변화, 사료섭취량, 혈중 대 사물질과 혈액상 변화를 조사하여 성장, 영양 소 이용성 및 산육생리와 관련된 기초 자료로 활용하고자 수행하였다.

\section{II. 재료 및 방법}

\section{1. 시험기간 및 공시동물}

본 연구에서 공시된 한우는 축산연구소에서 자체 생산된 생후 2 개월령 한우 송아지 50 두를 6개월령까지, 한우개량단지에서 구입한 생후 3 4개월령 한우 송아지 208두를 무혈거세기 (Burdizzo)를 이용하여 거세 후 생후 6 30개월 령까지 이용하였다.

\section{2. 시험구 배치 및 시험사료}

축산연구소에서 자체 생산된 송아지의 생후 2 6개월령까지의 시험구 배치는 별도의 처리 구분 없이 공시된 송아지 50 두 모두를 대상으 로 배합사료와 조사료를 자유 급여하였고, 구 입축 208 두의 시험구 배치는 생후 6 개월령까지 예비사양(배합사료와 조사료 자유급여)을 실시 하면서 월령과 체중을 고려하여 전기간 배합사 료 자유급여구와 육성기와 비육전기에 배합사 료 제한급여구 2개 처리구 및 성장월령별로 생 후 6 30개월까지 2 개월 간격의 13 구에 각 처리 별로 8 두씩을 완전임의 배치하였다 $(2$ 처리 $\times 13$ 구 $\times 8$ 반복 $=208$ 두). 본 시험에서 이용된 배합 사료는 육성기(생후 6 12개월령), 비육전기(생 후 13 18개월령) 및 비육후기(생후 19 30개월 령) 사료로 구분하였고, 조사료로는 절단 볏짚 을 이용하였으며, 비육단계별 배합사료의 배합 비와 시험사료의 성분은 각각 Table 1과 2에서 와 같다.

\section{3. 사양관리}

사료급여는 시험설계에 따라 배합사료 자유 급여구는 시험 전기간 동안 배합사료를 자유급 여하였고, 배합사료 제한급여구는 성장월령별 로 육성기에는 체중의 $1.2 \sim 1.5 \%$, 비육전기에는 체중의 $1.7 \sim 1.8 \%$, 비육후기에는 자유급여하였 다. 볏짚은 처리구에 관계없이 시험전기간 자 유급여하였으며, 물과 미네랄 블럭은 항상 자 유롭게 이용할 수 있도록 하였다. 
Table 1. Formula of experimental concentrates for various growing stages

\begin{tabular}{|c|c|c|c|}
\hline Ingredients (\%) & Grower $^{1)}$ & Fattener- I ${ }^{2)}$ & Fattener- $\Pi^{3)}$ \\
\hline Corn, ground & 33.93 & 32.98 & 49.76 \\
\hline Wheat, ground & 12.50 & 25.00 & 20.00 \\
\hline Corn gluten feed & - & - & 1.04 \\
\hline Wheat bran & 15.00 & 15.00 & 17.03 \\
\hline Tapioca & 6.00 & 9.00 & - \\
\hline Alfalfa & 5.00 & 1.00 & - \\
\hline Soybean meal & 1.00 & - & 0.60 \\
\hline Cottonseed meal & 5.00 & 3.64 & - \\
\hline Rapeseed meal & 8.00 & 4.04 & 5.00 \\
\hline Perilla meal & 5.00 & - & - \\
\hline Linseed meal & 1.25 & - & - \\
\hline Bypass fat & 0.57 & - & - \\
\hline Tallow & -- & 0.40 & - \\
\hline Cane molasses & 3.50 & 7.00 & 5.00 \\
\hline Limestone & 1.50 & 1.32 & 1.04 \\
\hline Tricalcium phosphate & 0.55 & - & - \\
\hline Salt, suncured & 0.70 & 0.40 & 0.40 \\
\hline Sodium bicarbonate & 0.12 & 0.12 & 0.12 \\
\hline Magnesium oxide & 0.08 & - & - \\
\hline Potassium sulfate & 0.20 & - & - \\
\hline Vitamin premix ${ }^{4}$ & 0.10 & - & - \\
\hline Mineral premix ${ }^{5}$ & - & 0.10 & 0.10 \\
\hline
\end{tabular}

1) Grower: concentrate feed for the growing stage (6 12 months of age).

${ }^{2)}$ Fattener- I : concentrate feed for the early fattening stage (13 18 months of age).

3) Fattener- $\Pi$ : concentrate feed for the late fattening stage (19 30 months of age).

4) Vitamin premix: vitamin $\mathrm{A}, 6,000 \mathrm{IU}$; vitamin $\mathrm{D}_{3}, 1,200 \mathrm{IU}$ per $\mathrm{kg}$.

5) Mineral premix: K, 0.08\%; S, 0.05\%; Fe, 30 ppm; Zn, 50 ppm; Mn, 40 ppm; Cu, 10 ppm; Co, 0.5 ppm; I, $0.53 \mathrm{ppm} ; \mathrm{Se}, 0.13 \mathrm{ppm}$; $\mathrm{Mg}, 0.03 \%$ per $\mathrm{kg}$.

\section{4. 조사 항목 및 분석 방법}

\section{(1) 증체량, 사료섭취량 조사 및 사료성분 분석} 체중은 전 시험기간 동안 10 일 간격으로 우 형기를 이용하여 측정하였으며, 산출된 일당증 체량을 기초로 하여 배합사료의 급여량을 조정 하였다. 사료섭취량은 매일 오전 사료 급여전 (08:00 a.m.)에 사료 잔량을 측정하여 산출하였 다. 시험사료의 일반성분은 시험기간 동안 1 개
월 간격으로 시료를 채취하여 $\mathrm{AOAC}(1995)$ 방 법에 준하여 분석하였다.

(2) 혈액 채취

공시된 시험축을 대상으로 출하전 공복시 생 후 2 30개월령까지 2개월 단위로 경정맥에서 채혈하여 분석하였는데, 생후 2 6개월령까지는 축산연구소에서 자체 생산된 송아지 50 두 모두 를 대상으로 채혈하였으며, 6 30개월령까지는 
Table 2. Chemical composition of concentrates and rice straw(as-fed basis)

\begin{tabular}{lcccc}
\hline Items & Grower & Fattener-I & Fattener-II & Rice straw \\
\hline \hline Moisture (\%) & 12.0 & 12.1 & 11.9 & 12.0 \\
Crude protein (\%) & 14.1 & 12.1 & 11.2 & 4.5 \\
Ether extract (\%) & 2.9 & 2.9 & 2.9 & 2.2 \\
Crude fiber (\%) & 3.1 & 3.2 & 3.1 & 28.3 \\
Crude ash (\%) & 5.6 & 5.4 & 5.2 & 15.1 \\
NFE & $(\%)$ & 64.3 & 65.7 & 38.0 \\
Calcium (\%) & 62.3 & 0.9 & 0.9 & 0.3 \\
Phosphorus (\%) & 1.0 & 0.4 & 0.3 & 0.1 \\
TDN $^{2)}(\%)$ & 0.5 & 70.6 & 71.9 & 38.0 \\
\hline
\end{tabular}

1) NFE: nitrogen-free extract.

2) TDN: Total digestible nutrients(calculated value).

2 개월 간격의 13 구에 각 처리별 8 두 $(2$ 처리 $\times 13$ 구 $\times 8$ 반복 $=208$ 두 $)$ 를 대상으로 채혈을 실시하 였다. 즉, Vacutainer(Heparin 무첨가)를 이용하 여 채취한 혈액을 $4{ }^{\circ} \mathrm{C}$ 에서 $18 \sim 24$ 시간 동안 정 치 후 원심분리 $(2000 \times \mathrm{g}, 15$ 분 $)$ 한 다음 상층액인 혈청을 회수하여 $-70^{\circ} \mathrm{C}$ 초저온 냉동고에 보관 하였고, 혈액상 분석을 위한 시료는 항응고제 인 EDTA $2 \mathrm{Na}(2 \mathrm{ml})$ 가 첨가된 시료병을 이용하 여 채취하였다.

\section{(3) 혈액성분 분석}

\section{1) 혈중 대사물질}

Albumin, glucose, blood urea nitrogen(BUN), total cholesterol, calcium 및 inorganic phosphorus (IP)는 Blood Chemistry Auto Analyzer(Expressplus 550, Ciba Corning, USA)를 이용하여 분석 하였다. 혈중 IGF-I(Insulin like growth factor-I) 의 분석은 Daughaday와 Rotwein(1989)의 방법에 준하여 Diagnostic Systems Laboratories(DSL5600 , USA)의 IGF-I coated-tube immuno-radio metric assay(IRMA) kit를 이용하여 혈청내의 IGF-I binding protein을 추출한 후 $\gamma$-counter ( $\mathrm{LKB}$, Qallay 1277, Gamma Master, USA)로 측 정하여 계산하였다.

\section{2) 혈액상}

혈액상 분석은 혈액 채취 직후 신선한 전혈 을 이용하여 혈구 자동 분석기인 Automatic
Blood Cell Counter(Serono System 9000, Switzerland)로 백혈구(WBC; White blood cell), 적혈구 (RBC; Red blood cell), 혈색소(Hb; Hemoglobin), 적혈구 용적률(HCT; Hematocrit), 평균적혈구용 적(MCV; Mean corpuscular volume), 평균적혈구 혈색소량(MCH; Mean corpuscular hemoglobin) 및 평균적혈구혈색소농도(MCHC; Mean corpuscular hemoglobin concentration) 등을 조사하였다.

\section{5. 통계분석}

본 시험에서 얻어진 성적들은 SAS package (1999)를 이용하여 분산분석 및 t-검정을 실시 하여 처리구간의 유의성 $(\mathrm{p}<0.05)$ 을 검증하였다.

\section{III. 결과 및 고찰}

\section{1. 증체, 사료섭취량 및 사료요구율}

육성기 및 비육전기 배합사료 자유급여와 제 한급여가 한우 거세우의 성장월령별 증체, 사 료섭취량 및 사료요구율에 미치는 영향은 Table 3 에서와 같다. 생후 2 6개월령까지는 처리에 관계없이 사료급여 형태는 배합사료 자유급여 였으며, $\mathrm{T} 1$ 구 (전기간 배합사료 자유급여구)와 $\mathrm{T} 2$ 구(생후 6 18개월령 배합사료 제한급여구)로 사료급여 형태가 구분되는 시점인 생후 6 개월 
Table 3. Effects of ad libitum and restricted feeding of concentrates on body weight gain, feed intake and feed conversion in Hanwoo steers

\begin{tabular}{|c|c|c|c|c|c|c|c|}
\hline Age, mo & Treatment $^{1)}$ & $\mathrm{BW}^{2}(\mathrm{~kg})$ & $\mathrm{ADG}^{3}(\mathrm{~kg} / \mathrm{d})$ & $\mathrm{Cl}^{4}(\mathrm{~kg})$ & $\mathrm{RI}^{5}(\mathrm{~kg})$ & $\mathrm{TDMI}^{6}(\mathrm{~kg})$ & $\mathrm{FC}^{7)}$ \\
\hline 2 & - & $63.8 \pm 5.4$ & - & - & - & - & - \\
\hline 4 & - & $81.2 \pm 4.0$ & - & - & - & - & - \\
\hline 6 & - & $142.8 \pm 5.1$ & - & - & - & - & - \\
\hline \multirow{2}{*}{8} & $\mathrm{~T} 1$ & $200.9 \pm 6.1$ & $0.91 \pm 0.03$ & $3.9 \pm 0.1$ & $1.5 \pm 0.1$ & $5.4 \pm 0.3$ & $5.9 \pm 0.3$ \\
\hline & $\mathrm{T} 2$ & $200.2 \pm 5.0$ & $0.81 \pm 0.04$ & $4.1 \pm 0.2$ & $1.6 \pm 0.0$ & $5.7 \pm 0.4$ & $7.0 \pm 0.6$ \\
\hline \multirow{2}{*}{10} & $\mathrm{~T} 1$ & $251.9 \pm 6.7$ & $0.98 \pm 0.05^{\mathrm{a}}$ & $6.1 \pm 0.4^{\mathrm{a}}$ & $1.0 \pm 0.0^{\mathrm{b}}$ & $7.1 \pm 0.6^{\mathrm{a}}$ & $7.2 \pm 0.5$ \\
\hline & $\mathrm{T} 2$ & $235.0 \pm 5.9$ & $0.63 \pm 0.02^{b}$ & $2.9 \pm 0.1^{\mathrm{b}}$ & $2.3 \pm 0.2^{\mathrm{a}}$ & $5.2 \pm 0.4^{\mathrm{b}}$ & $8.3 \pm 0.6$ \\
\hline \multirow[b]{2}{*}{12} & $\mathrm{~T} 1$ & $313.5 \pm 7.0^{\mathrm{a}}$ & $0.96 \pm 0.04^{\mathrm{a}}$ & $7.4 \pm 0.6^{\mathrm{a}}$ & $0.9 \pm 0.0^{b}$ & $8.3 \pm 0.5^{\mathrm{a}}$ & $8.6 \pm 0.5$ \\
\hline & $\mathrm{T} 2$ & $265.5 \pm 6.3^{b}$ & $0.62 \pm 0.05^{\mathrm{b}}$ & $3.4 \pm 0.4^{\mathrm{b}}$ & $2.7 \pm 0.1^{\mathrm{a}}$ & $6.1 \pm 0.3^{\mathrm{b}}$ & $9.8 \pm 0.3$ \\
\hline \multirow{2}{*}{14} & $\mathrm{~T} 1$ & $372.1 \pm 7.8^{\mathrm{a}}$ & $0.84 \pm 0.04^{\mathrm{a}}$ & $7.0 \pm 0.5^{\mathrm{a}}$ & $0.9 \pm 0.1^{b}$ & $7.9 \pm 0.4$ & $9.4 \pm 0.2$ \\
\hline & $\mathrm{T} 2$ & $310.2 \pm 6.5^{b}$ & $0.76 \pm 0.03^{\mathrm{b}}$ & $4.4 \pm 0.3^{\mathrm{b}}$ & $3.0 \pm 0.3^{\mathrm{a}}$ & $7.4 \pm 0.5$ & $9.7 \pm 0.4$ \\
\hline \multirow{2}{*}{16} & $\mathrm{~T} 1$ & $417.5 \pm 8.5^{\mathrm{a}}$ & $0.81 \pm 0.05$ & $8.3 \pm 0.4^{\mathrm{a}}$ & $1.2 \pm 0.2^{b}$ & $9.5 \pm 0.7^{\mathrm{a}}$ & $11.7 \pm 0.6$ \\
\hline & $\mathrm{T} 2$ & $359.9 \pm 7.2^{b}$ & $0.73 \pm 0.04$ & $5.7 \pm 0.2^{\mathrm{b}}$ & $2.4 \pm 0.3^{\mathrm{a}}$ & $8.1 \pm 0.5^{\mathrm{b}}$ & $11.1 \pm 0.5$ \\
\hline \multirow{2}{*}{18} & $\mathrm{~T} 1$ & $464.7 \pm 8.4^{\mathrm{a}}$ & $0.69 \pm 0.02$ & $8.0 \pm 0.5^{\mathrm{a}}$ & $1.3 \pm 0.2^{\mathrm{b}}$ & $9.3 \pm 0.5$ & $13.5 \pm 0.7$ \\
\hline & $\mathrm{T} 2$ & $401.2 \pm 8.5^{\mathrm{b}}$ & $0.71 \pm 0.06$ & $6.6 \pm 0.3^{b}$ & $2.4 \pm 0.4^{\mathrm{a}}$ & $9.0 \pm 0.3$ & $12.7 \pm 0.4$ \\
\hline \multirow{2}{*}{20} & $\mathrm{~T} 1$ & $496.9 \pm 9.9^{\mathrm{a}}$ & $0.58 \pm 0.03^{b}$ & $7.9 \pm 0.4$ & $1.5 \pm 0.2^{b}$ & $9.4 \pm 0.3$ & $16.2 \pm 0.6^{\mathrm{a}}$ \\
\hline & $\mathrm{T} 2$ & $442.8 \pm 9.3^{b}$ & $0.73 \pm 0.07^{\mathrm{a}}$ & $7.7 \pm 0.5$ & $2.5 \pm 0.3^{\mathrm{a}}$ & $10.2 \pm 0.6$ & $14.0 \pm 0.3^{b}$ \\
\hline \multirow{2}{*}{22} & $\mathrm{~T} 1$ & $537.6 \pm 10.3$ & $0.64 \pm 0.04^{b}$ & $7.4 \pm 0.3^{b}$ & $1.4 \pm 0.2$ & $8.8 \pm 0.4^{b}$ & $13.8 \pm 0.5$ \\
\hline & $\mathrm{T} 2$ & $498.4 \pm 10.4$ & $0.86 \pm 0.07^{\mathrm{a}}$ & $9.2 \pm 0.6^{\mathrm{a}}$ & $1.4 \pm 0.1$ & $10.6 \pm 0.5^{\mathrm{a}}$ & $12.3 \pm 0.2$ \\
\hline \multirow{2}{*}{24} & $\mathrm{~T} 1$ & $571.6 \pm 12.0$ & $0.55 \pm 0.04^{b}$ & $7.9 \pm 0.4$ & $1.3 \pm 0.1$ & $9.2 \pm 0.3$ & $16.7 \pm 0.7^{\mathrm{a}}$ \\
\hline & $\mathrm{T} 2$ & $545.9 \pm 11.5$ & $0.71 \pm 0.08^{\mathrm{a}}$ & $8.4 \pm 0.3$ & $1.0 \pm 0.0$ & $9.4 \pm 0.5$ & $13.2 \pm 0.4^{\mathrm{b}}$ \\
\hline \multirow{2}{*}{26} & $\mathrm{~T} 1$ & $599.4 \pm 13.0$ & $0.49 \pm 0.02$ & $7.5 \pm 0.4$ & $1.3 \pm 0.2$ & $8.8 \pm 0.4$ & $17.9 \pm 0.5^{\mathrm{a}}$ \\
\hline & $\mathrm{T} 2$ & $577.6 \pm 16.1$ & $0.58 \pm 0.05$ & $7.4 \pm 0.3$ & $1.1 \pm 0.2$ & $8.5 \pm 0.2$ & $14.7 \pm 0.2^{\mathrm{b}}$ \\
\hline \multirow{2}{*}{28} & $\mathrm{~T} 1$ & $632.5 \pm 15.2$ & $0.56 \pm 0.06$ & $8.0 \pm 0.5$ & $1.4 \pm 0.3$ & $9.4 \pm 0.5$ & $16.8 \pm 0.6^{\mathrm{a}}$ \\
\hline & $\mathrm{T} 2$ & $613.3 \pm 16.3$ & $0.64 \pm 0.05$ & $7.5 \pm 0.4$ & $1.3 \pm 0.2$ & $8.8 \pm 0.3$ & $13.8 \pm 0.4^{\mathrm{b}}$ \\
\hline \multirow{2}{*}{30} & $\mathrm{~T} 1$ & $670.0 \pm 18.8$ & $0.60 \pm 0.07^{b}$ & $8.5 \pm 0.5$ & $1.5 \pm 0.4$ & $10.0 \pm 0.7$ & $16.7 \pm 0.7^{\mathrm{a}}$ \\
\hline & $\mathrm{T} 2$ & $647.8 \pm 20.9$ & $0.73 \pm 0.08^{\mathrm{a}}$ & $8.8 \pm 0.6$ & $1.4 \pm 0.3$ & $10.2 \pm 0.6$ & $13.9 \pm 0.3^{b}$ \\
\hline
\end{tabular}

Mean \pm S.D.

a, b Means with different superscripts in the same column differ significantly $(\mathrm{p}<0.05)$.

1) T1: ad libitum feeding of concentrates; T2: restricted feeding of concentrates.

${ }^{2)} \mathrm{BW}$ : body weight; ${ }^{3)} \mathrm{ADG}$ : average daily gain; ${ }^{4)} \mathrm{CI}$ : concentrate intake; ${ }^{5)} \mathrm{RI}$ : rice straw intake;

${ }^{6}$ TDMI: total dry matter intake; ${ }^{7)} \mathrm{FC}$ : feed conversion(feed/gain, kg/kg).

령의 평균체중은 $142.8 \mathrm{~kg}$ 이었다. 생후 $8 \sim 10$ 개 월령까지 4개월 동안에는 사료급여 형태가 달 랐음에도 불구하고 처리간 증체의 차이는 없었 으나, 생후 12 20개월령까지는 $\mathrm{T} 2$ 구에 비해 T1 구의 체중이 유의적으로 높았다 $(\mathrm{p}<0.05)$. 사료 급여 형태가 자유급여로 전환된 생후 18 개월령 이후부터는 처리간의 일당증체량 차이는 점차 적으로 감소하여 생후 20 24개월령에는 T1구에 비해 오히려 $\mathrm{T} 2$ 구의 일당증체량이 많았다 $(\mathrm{p}<0.05)$.

본 시험에서 나타난 결과는 Murphy와 Loerch (1994)가 평균체중 $280 \mathrm{~kg}$ 의 교잡종 거세우 (Continental $\times$ English breeds) 36두를 대상으로 배합사료 자유급여구, 배합사료 제한급여 1 구 (자유급여구의 90\%) 및 배합사료 제한급여 2구 (자유급여구의 $80 \%$ )로 구분하여 실험한 결과 자유급여구에 비해 제한급여 1 및 2 구의 육성 기와 비육기의 일당증체량이 각각 0.15 와 0.24 
$\mathrm{kg}$ 및 0.12 와 $0.21 \mathrm{~kg}$ 감소했다는 결과와 유사 한 경향을 보였다. 또한 처리에 관계없이 본 시험에서 나타난 한우 거세우의 체중은 백 등 (1989)이 한우 거세우를 생후 6개월령부터 육성 비육한 결과 생후 $6,12,18$ 및 21 개월령의 체 중이 각각 $137.3,315.2,466.5$ 및 $531.1 \mathrm{~kg}$ 이었 다는 보고와도 유사한 수준이었다.

한편, 거세우에서 자유급여에 비해 전기간 제한급여시 육성기의 일당증체량은 감소되고 동일 체중 도달을 위한 사육기간은 증가하지 만, 비육후기에 자유급여로 전환시 증체량의 차이는 없어질 뿐만 아니라 육성기 제한급여로 증체에 대한 부의 영향은 없기 때문에 일정기 간 사료섭취량의 제한은 긍정적인 사양방법인 것으로 보고된 바 있다(Loerch, 1990; Murphy 등, 1994b). 본 시험의 결과에서도 배합사료 제 한급여로 인해 대략 6개월(생후 10 14개월령) 동안 증체 및 일당증체량이 감소하는 현상을 보였으나, 14 개월령 이후 증체의 처리간 차이 는 점차적으로 줄어들어 21 개월령 이후에는 보 상성장으로 인해 체중 차이가 없어지며 일당증 체량은 오히려 증가하는 현상을 나타내어 육성 기 및 비육전기 동안 사료섭취량 제한에 따른 거세우의 비육후기 성장에 대한 부의 영향은 없었다.

한편, 배합사료 섭취량의 경우 처리간 체중 증가 및 일당증체량과 유사한 경향을 보였는 데, 생후 10 18개월령까지는 $\mathrm{T} 2$ 구에 비해 $\mathrm{T} 1$ 구 에서 자유급여로 인해 배합사료 섭취량이 많았 으나 $(\mathrm{p}<0.05)$, 비육후기인 22개월령에는 $\mathrm{T} 1$ 구에 비해 $\mathrm{T} 2$ 구에서 배합사료 섭취량이 많았으며 $(\mathrm{p}<0.05)$, 생후 $24 \sim 30$ 개월령까지도 대체적으로 $\mathrm{T} 1$ 구에 비해 $\mathrm{T} 2$ 구의 배합사료 섭취량이 증가 하는 경향이었다. 반면에 볏짚 섭취량의 경우 생후 10 20개월령까지 $\mathrm{T} 1$ 구에 비해 $\mathrm{T} 2$ 구에서 많았으나 $(\mathrm{p}<0.05), 22$ 개월령 이후부터는 처리간 에 볏짚 섭취량의 차이는 없었다. 따라서 총건 물섭취량의 경우 생후 10,12 및 16 개월령에는 $\mathrm{T} 1$ 구에서, 22 개월령에는 $\mathrm{T} 2$ 구에서 상대적으로 높은 결과 $(\mathrm{p}<0.05)$ 를 보였을 뿐 여타 월령에서 는 큰 차이를 보이지 않았는데, 이와 같은 결 과는 $\mathrm{T} 1$ 구의 경우 전기간 배합사료 자유급여로
인해 볏짚 섭취량이 상대적으로 적어진 반면에 $\mathrm{T} 2$ 구는 배합사료 제한급여 기간 동안에는 더 많은 볏짚 섭취를 통해 건물섭취량을 충족시킨 데 원인이 있는 것으로 판단된다. Hermesmeyer 등(2002)이 Angus 거세우를 대상으로 배합사료 자유급여구와 제한급여구(자유급여구의 $75 \%$ )로 실험한 결과 자유급여구에 비해 제한급여구에 서 건물섭취량은 $15.5 \%$ 적었다고 보고한 바 있 으며, 본 시험에서는 자유급여구에 비해 제한 급여구의 시험전기간 건물섭취량이 대략 $4 \%$ 정도 적은 것으로 나타나 이전의 보고에 비해 다소 건물섭취량 감소가 적은 것으로 나타났는 데, 이는 홍 등(1996)의 사료의 제한급여 수준, 품종, 사육기간 등의 차이에서 기인하는 것과 같은 결과를 보였다.

Murphy와 Loerch(1994)는 거세우의 육성기 및 비육기 동안의 제한급여는 자유급여시에 비 해 사료요구율이 감소되고, Murphy 등(1994a)은 자유급여에 비해 제한급여시 건물, $\mathrm{NDF}$ 및 외 관상 질소 소화율이 건물섭취량 $1 \mathrm{~kg}$ 제한시 마다 각각 $2.8,4.1$ 및 $6.2 \%$ 증가되는 것으로 보고한 바 있다. 이 외에도 여러 연구자들에 의해 거세우에서 일정기간의 제한급여는 사료 요구율에 영향을 미치지 않거나(Murphy 등, 1994b) 사료요구율을 유의적으로 감소(Andersen 과 Ingvartsen, 1984; Loerch, 1990)시키는 것으 로 보고되어 왔다. 본 시험의 결과에서도 사료 요구율의 경우 생후 18 개월령까지는 처리간에 차이를 보이지 않았으나, 생후 20 30개월령까 지는 $\mathrm{T} 1$ 구에 비해 $\mathrm{T} 2$ 구에서 사료요구율이 유 의적으로 감소되는 결과 $(\mathrm{p}<0.05)$ 를 보여 이전의 연구결과들과 유사한 경향을 보였으며, 육성기 및 비육전기 동안 부분적인 사료섭취량 제한은 비육후기의 사료요구율을 감소시키는 것으로 판단된다.

\section{2. 혈중 대사물질}

육성기 및 비육전기 배합사료 제한급여가 한 우 거세우의 혈중 albumin, BUN, cholesterol 및 triglyceride 등 혈청 화학치 변화에 미치는 영향 은 Table 4에서와 같다. 
Table 4. Effects of ad libitum and restricted feeding of concentrates on serum albumin, BUN, cholesterol and triglyceride concentrations in Hanwoo steers

\begin{tabular}{|c|c|c|c|c|c|}
\hline Age, mo & Treatment $^{1)}$ & $\mathrm{Alb}^{2)}(\mathrm{g} / \mathrm{dl})$ & $\mathrm{BUN}^{3}(\mathrm{mg} / \mathrm{dl})$ & $\mathrm{Chol}^{4)}(\mathrm{mg} / \mathrm{dl})$ & $\mathrm{Tg}^{5)}(\mathrm{mg} / \mathrm{dl})$ \\
\hline 2 & -- & $3.6 \pm 0.2$ & $9.2 \pm 2.6$ & $151.8 \pm 28.6$ & $30.3 \pm 17.4$ \\
\hline 4 & -- & $3.7 \pm 0.1$ & $9.1 \pm 2.8$ & $134.6 \pm 29.7$ & $14.8 \pm 7.8$ \\
\hline 6 & -- & $3.4 \pm 0.2$ & $16.2 \pm 4.6$ & $89.1 \pm 11.7$ & $8.0 \pm 4.2$ \\
\hline \multirow{2}{*}{8} & $\mathrm{~T} 1$ & $3.2 \pm 0.2$ & $14.0 \pm 0.8$ & $116.0 \pm 8.2$ & $19.0 \pm 3.3$ \\
\hline & $\mathrm{T} 2$ & $3.6 \pm 0.3$ & $13.0 \pm 1.4$ & $94.0 \pm 20.9$ & $17.4 \pm 4.5$ \\
\hline \multirow{2}{*}{10} & $\mathrm{~T} 1$ & $3.4 \pm 0.2$ & $15.1 \pm 1.9$ & $123.6 \pm 10.3$ & $27.9 \pm 1.0$ \\
\hline & $\mathrm{T} 2$ & $3.7 \pm 0.4$ & $14.3 \pm 2.4$ & $108.0 \pm 21.6$ & $25.7 \pm 25.2$ \\
\hline \multirow{2}{*}{12} & $\mathrm{~T} 1$ & $3.2 \pm 0.2^{\mathrm{b}}$ & $14.4 \pm 1.1$ & $112.0 \pm 16.4$ & $19.6 \pm 2.4$ \\
\hline & $\mathrm{T} 2$ & $3.5 \pm 0.2^{\mathrm{a}}$ & $13.6 \pm 2.6$ & $105.2 \pm 20.8$ & $17.1 \pm 11.1$ \\
\hline \multirow{2}{*}{14} & $\mathrm{~T} 1$ & $3.0 \pm 0.2^{\mathrm{b}}$ & $14.3 \pm 1.4$ & $104.7 \pm 7.2$ & $16.8 \pm 1.9^{\mathrm{a}}$ \\
\hline & $\mathrm{T} 2$ & $3.2 \pm 0.2^{\mathrm{a}}$ & $13.3 \pm 1.2$ & $96.3 \pm 9.5$ & $14.2 \pm 2.7^{b}$ \\
\hline \multirow{2}{*}{16} & $\mathrm{~T} 1$ & $3.1 \pm 0.2^{b}$ & $15.1 \pm 1.2$ & $126.5 \pm 8.7$ & $10.3 \pm 1.3^{\mathrm{a}}$ \\
\hline & $\mathrm{T} 2$ & $3.4 \pm 0.2^{\mathrm{a}}$ & $14.8 \pm 1.3$ & $114.6 \pm 11.9$ & $8.4 \pm 1.0^{\mathrm{b}}$ \\
\hline \multirow{2}{*}{18} & $\mathrm{~T} 1$ & $3.2 \pm 0.2^{\mathrm{b}}$ & $17.0 \pm 1.5$ & $142.6 \pm 13.0$ & $7.3 \pm 0.5$ \\
\hline & $\mathrm{T} 2$ & $3.4 \pm 0.1^{\mathrm{a}}$ & $16.7 \pm 1.3$ & $128.4 \pm 17.3$ & $6.8 \pm 2.0$ \\
\hline \multirow{2}{*}{20} & $\mathrm{~T} 1$ & $3.5 \pm 0.3$ & $16.8 \pm 2.4$ & $153.1 \pm 14.3$ & $17.1 \pm 3.4$ \\
\hline & $\mathrm{T} 2$ & $3.7 \pm 0.3$ & $16.4 \pm 2.5$ & $148.7 \pm 17.2$ & $16.2 \pm 14.9$ \\
\hline \multirow{2}{*}{22} & $\mathrm{~T} 1$ & $3.5 \pm 0.0$ & $15.6 \pm 2.5$ & $155.3 \pm 7.1$ & $9.7 \pm 3.3$ \\
\hline & $\mathrm{T} 2$ & $3.5 \pm 0.2$ & $15.2 \pm 1.2$ & $143.9 \pm 20.5$ & $10.8 \pm 2.6$ \\
\hline \multirow{2}{*}{24} & $\mathrm{~T} 1$ & $3.5 \pm 0.5$ & $15.6 \pm 2.4$ & $131.5 \pm 12.1$ & $20.7 \pm 2.4$ \\
\hline & $\mathrm{T} 2$ & $3.5 \pm 0.2$ & $16.4 \pm 2.5$ & $137.0 \pm 15.1$ & $20.3 \pm 4.1$ \\
\hline \multirow{2}{*}{26} & $\mathrm{~T} 1$ & $3.9 \pm 0.2$ & $14.6 \pm 1.4$ & $113.9 \pm 19.4$ & $8.4 \pm 3.5$ \\
\hline & $\mathrm{T} 2$ & $4.0 \pm 0.1$ & $15.0 \pm 2.1$ & $147.0 \pm 36.9$ & $5.2 \pm 2.4$ \\
\hline \multirow{2}{*}{28} & $\mathrm{~T} 1$ & $3.9 \pm 0.3$ & $14.6 \pm 1.7$ & $135.4 \pm 20.7$ & $5.4 \pm 2.1$ \\
\hline & $\mathrm{T} 2$ & $4.0 \pm 0.2$ & $15.7 \pm 1.4$ & $155.9 \pm 24.3$ & $4.8 \pm 3.1$ \\
\hline \multirow{2}{*}{30} & $\mathrm{~T} 1$ & $4.1 \pm 0.2$ & $14.5 \pm 2.9$ & $121.0 \pm 21.9$ & $6.3 \pm 2.7$ \\
\hline & $\mathrm{T} 2$ & $3.9 \pm 0.3$ & $13.8 \pm 2.3$ & $126.6 \pm 25.1$ & $6.6 \pm 2.7$ \\
\hline
\end{tabular}

Mean \pm S.D.

a,b Means with different superscripts in the same column differ significantly $(\mathrm{p}<0.05)$.

1) T1: ad libitum feeding of concentrates; T2: restricted feeding of concentrates.

2) Alb: albumin; ${ }^{3)}$ BUN: blood urea nitrogen; ${ }^{4)}$ Chol: cholesterol; ${ }^{5)} \mathrm{Tg}$ : triglyceride.

$\mathrm{T} 1$ 구와 $\mathrm{T} 2$ 구의 생후 $12,14,16$ 및 18 개월령 의 혈중 albumin 농도는 각각 $3.2 \mathrm{vs} 3.5,3.0 \mathrm{vs}$ $3.2,3.1$ vs 3.4 및 3.2 vs $3.4 \mathrm{~g} / \mathrm{d} \ell$ 로 나타나 $\mathrm{T} 1$ 구에 비해 $\mathrm{T} 2$ 구의 혈중 albumin 농도가 높았다 $(\mathrm{p}<0.05)$. 혈중 albumin 농도의 감소는 체조직의 단백질 합성량이 증가하여 전구물질인 albumin 농도가 낮아지는데 원인이 있으며(길, 1999), Galbraith 등(1978)은 Friesian 종 비거세우 및 거 
세우를 대상으로 실험한 결과 충분한 에너지를 공급하여 사육할 경우 상대적으로 증체가 왕성 한 비거세우가 거세우에 비해 혈중 albumin 농 도가 현저히 감소되는 것으로 보고하여, 본 시 험에서 일당증체량 및 배합사료 섭취량이 낮았 던 T2구에서 $\mathrm{T} 1$ 구에 비해 생후 12 18개월령 혈중 albumin 농도가 높았던 것으로 판단된다. 그러나 생후 12 18개월령을 제외한 다른 월령 에서는 처리간의 albumin 농도 차이는 없었고, 비육후기인 20 30개월령의 경우 배합사료 제한 급여를 해제시 혈중 albumin 농도 역시 처리간 에 차이가 없었다. 본 시험에서 $\mathrm{BUN}$ 및 혈중 cholesterol 농도의 경우 시험전기간 동안 처리 간에 큰 차이를 보이지는 않았으나, 생후 20 개 월령 전후까지 배합사료 섭취량이 적었던 $\mathrm{T} 2$ 구 에 비해 상대적으로 배합사료 섭취량이 많았던 $\mathrm{T} 1$ 구에서 $\mathrm{BUN}$ 농도가 높은 경향을 보였는데 ( $>>0.05)$, Huntington 등(1996)이 비육전기 거세 우를 대상으로 배합사료 급여량이 증가할수록 $\mathrm{BUN}$ 농도가 증가했다는 보고와 유사한 경향을 보인 것으로 판단된다.

또한 Arave 등(1975)은 발육 및 사료에너지 섭취가 증가할수록 혈중 cholesterol 농도는 증 가하는 것으로 보고한 바 있는데, 본 시험의 결과에서도 배합사료 섭취량이 상대적으로 많 았던 $\mathrm{T} 1$ 구에서 $\mathrm{T} 2$ 구에 비해 생후 20 개월령 전 후까지 혈중 cholesterol 농도가 높은 경향을 보 였다 $(\mathrm{p}>0.05)$.

한편, 생후 14 및 16 개월령의 $\mathrm{T} 1$ 구와 $\mathrm{T} 2$ 구의 혈중 triglyceride 농도는 각각 16.8 vs 14.2 및 10.3 vs $8.4 \mathrm{mg} / \mathrm{ml}$ 로 나타나 $\mathrm{T} 2$ 구에 비해 $\mathrm{T} 1$ 구 에서 유의적으로 높은 것으로 나타나 $(\mathrm{p}<0.05)$ 배합사료 섭취량에 따라 혈중 중성지방인 triglyceride 농도가 상대적으로 달라질 수도 있 는 것으로 판단되지만, 여타 월령에서는 처리 간에 차이는 없었다.

육성기 및 비육전기 배합사료 제한급여가 한 우 거세우의 혈청화학치중 혈중 IGF-I, glucose, IP 및 calcium 농도 변화에 미치는 영향은 Table 5에서와 같다.

IGF-I은 분자량 $7.6 \mathrm{kd}$ 로 70 개의 아미노산으 로 구성된 펩타이드호르몬으로서 구조적으로는
IGF-II와 Insulin과 유사하고, $\mathrm{GH}$ 에 의존하여 생 식선을 비롯하여 간, 신장 및 체내 대부분의 주요조직에서 합성 분비되어 각 조직의 기능유 지에 중요한 역할을 담당하고 있으며 혈중에 안정적으로 존재하고 특히, $\mathrm{GH}$ 의 분비에 관여 하는 주요한 성장인자로 알려져 있다(Winger 등, 1997).

생후 2 및 6 개월령의 혈중 IGF-I 농도는 차 이 없이 각각 217.3 및 $228.8 \mathrm{ng} / \mathrm{ml}$ 으로 나타났 으며, 사료 급여 방법을 달리한 후 2 개월이 경 과한 8개월령의 혈중 IGF-I 농도 역시 처리간 에 차이가 없는 것으로 나타났다. 그러나 10 14개월령까지 T2구의 혈중 IGF-I 농도는 T1 구에 비해 비록 통계적인 유의성은 인정되지 않았으나 일시적으로 낮아지는 경향을 보였는 데( $\mathrm{p}>0.05)$, 이 시기에 $\mathrm{T} 1$ 구에 비해 $\mathrm{T} 2$ 구의 체 중, 일당증체량 및 배합사료 섭취량이 유의적 $(\mathrm{p}<0.05)$ 으로 낮은데 원인(Table 3$)$ 이 있는 것으 로 판단된다.

이와 같은 결과로 볼 때 $\mathrm{T} 1$ 구와 $\mathrm{T} 2$ 구간에 증체량의 차이를 보이는 월령에서 혈중 IGF-I 농도의 차이가 나타난 것은 혈중 IGF-I은 거세 우의 성장능력을 간접적으로 확인하는데 이용 될 수도 있을 것으로 판단된다.

한편, $\mathrm{T} 1$ 구와 $\mathrm{T} 2$ 구의 생후 $8,10,16$ 및 22개 월령의 혈중 IP 농도는 각각 $7.5 \mathrm{vs} 9.8,9.7 \mathrm{vs}$ $10.7,7.8$ vs 8.2 및 6.0 vs $7.0 \mathrm{mg} / \mathrm{dl}$ 로 나타나 $\mathrm{T} 1$ 구에 비해 $\mathrm{T} 2$ 구에서 높았으나 $(\mathrm{p}<0.05)$, 다른 월령에서는 처리간의 차이는 없었다.

혈중 calcium 농도의 경우 처리 혹은 월령에 관계없이 시험전기간 동안 $9.2 \sim 11.3 \mathrm{mg} / \mathrm{dl}$ 의 범 위로 나타났으며, IP와 마찬가지로 calcium 농 도의 경우도 처리간의 차이는 크지 않았고, 본 시험에서 조사된 혈액성분 중에서 항상성이 상대적으로 높은 경향을 보였다. 혈중 $\mathrm{IP}$ 와 calcium 농도는 체내 각종 호르몬(부갑상선)에 의해 조절되며, 골격의 주된 조성분으로 골격 성장과 밀접한 관련이 있는 것으로 알려져 왔 는데(임, 2001), 본 시험에서 처리에 관계없이 거세우의 혈중 IP 및 calcium 농도는 임 (2001) 이 한우 거세우의 혈중 IP 및 calcium 농도가 각각 7.44 및 $9.59 \mathrm{mg} / \mathrm{dl}$ 이었다는 보고와 유사 
Table 5. Effects of ad libitum and restricted feeding of concentrates on serum IGF-I, glucose, inorganic phosphorus and calcium concentrations in Hanwoo steers

\begin{tabular}{|c|c|c|c|c|c|}
\hline Age, mo & Treatment $^{1)}$ & IGF-I $^{2)}(\mathrm{ng} / \mathrm{ml})$ & $\mathrm{Glu}^{3)}(\mathrm{mg} / \mathrm{dl})$ & $\mathrm{IP}^{4)}(\mathrm{mg} / \mathrm{dl})$ & $\mathrm{Ca}^{5}(\mathrm{mg} / \mathrm{dl})$ \\
\hline 2 & -- & $217.3 \pm 46.4$ & $99.5 \pm 13.8$ & $10.3 \pm 0.6$ & $11.3 \pm 0.7$ \\
\hline 4 & -- & $253.7 \pm 43.2$ & $94.6 \pm 3.6$ & $9.5 \pm 0.5$ & $10.3 \pm 0.3$ \\
\hline 6 & -- & $228.8 \pm 155.0$ & $86.3 \pm 17.4$ & $8.8 \pm 1.4$ & $10.5 \pm 0.8$ \\
\hline \multirow{2}{*}{8} & $\mathrm{~T} 1$ & $107.7 \pm 16.6$ & $78.0 \pm 8.2$ & $7.5 \pm 0.2^{b}$ & $10.9 \pm 0.3$ \\
\hline & $\mathrm{T} 2$ & $107.8 \pm 45.7$ & $75.8 \pm 17.0$ & $9.8 \pm 0.8^{\mathrm{a}}$ & $10.8 \pm 0.4$ \\
\hline \multirow{2}{*}{10} & $\mathrm{~T} 1$ & $229.9 \pm 126.1$ & $80.6 \pm 10.5$ & $9.7 \pm 0.2^{b}$ & $10.9 \pm 0.5$ \\
\hline & $\mathrm{T} 2$ & $141.8 \pm 67.2$ & $76.8 \pm 18.0$ & $10.7 \pm 0.2^{\mathrm{a}}$ & $10.9 \pm 0.6$ \\
\hline \multirow{2}{*}{12} & $\mathrm{~T} 1$ & $172.8 \pm 103.4$ & $91.1 \pm 6.4$ & $7.9 \pm 0.2$ & $10.8 \pm 0.8$ \\
\hline & $\mathrm{T} 2$ & $99.4 \pm 65.5$ & $88.2 \pm 8.8$ & $8.5 \pm 1.1$ & $10.8 \pm 0.5$ \\
\hline \multirow{2}{*}{14} & $\mathrm{~T} 1$ & $304.5 \pm 128.0$ & $85.2 \pm 4.4$ & $7.7 \pm 0.3$ & $10.6 \pm 0.5$ \\
\hline & $\mathrm{T} 2$ & $245.6 \pm 103.5$ & $81.9 \pm 4.2$ & $8.0 \pm 0.4$ & $10.2 \pm 0.4$ \\
\hline \multirow{2}{*}{16} & $\mathrm{~T} 1$ & $293.9 \pm 153.5$ & $86.2 \pm 7.1$ & $7.8 \pm 0.2^{b}$ & $10.5 \pm 0.5$ \\
\hline & $\mathrm{T} 2$ & $383.3 \pm 132.6$ & $84.6 \pm 6.4$ & $8.2 \pm 0.3^{\mathrm{a}}$ & $10.2 \pm 0.4$ \\
\hline \multirow{2}{*}{18} & $\mathrm{~T} 1$ & $241.3 \pm 105.2$ & $84.9 \pm 5.4$ & $7.9 \pm 0.2$ & $10.3 \pm 0.6$ \\
\hline & $\mathrm{T} 2$ & $299.7 \pm 148.3$ & $85.6 \pm 7.1$ & $8.0 \pm 0.5$ & $10.1 \pm 0.2$ \\
\hline \multirow{2}{*}{20} & $\mathrm{~T} 1$ & $264.3 \pm 83.1$ & $75.6 \pm 4.2$ & $8.2 \pm 0.3$ & $10.1 \pm 0.3$ \\
\hline & $\mathrm{T} 2$ & $241.6 \pm 111.8$ & $77.4 \pm 9.2$ & $8.3 \pm 0.5$ & $10.3 \pm 0.4$ \\
\hline \multirow{2}{*}{22} & $\mathrm{~T} 1$ & $366.6 \pm 125.3$ & $56.3 \pm 6.3^{b}$ & $6.0 \pm 0.8^{\mathrm{b}}$ & $9.9 \pm 0.4$ \\
\hline & $\mathrm{T} 2$ & $344.6 \pm 108.6$ & $74.1 \pm 7.9^{\mathrm{a}}$ & $7.0 \pm 0.4^{\mathrm{a}}$ & $10.0 \pm 0.6$ \\
\hline \multirow{2}{*}{24} & $\mathrm{~T} 1$ & $179.0 \pm 60.2$ & $75.8 \pm 11.0$ & $7.3 \pm 0.9$ & $9.5 \pm 0.5$ \\
\hline & $\mathrm{T} 2$ & $280.0 \pm 106.8$ & $80.2 \pm 7.4$ & $6.9 \pm 0.6$ & $9.8 \pm 0.4$ \\
\hline \multirow{2}{*}{26} & $\mathrm{~T} 1$ & $273.3 \pm 73.1$ & $75.7 \pm 4.3$ & $6.9 \pm 0.6$ & $9.3 \pm 0.6$ \\
\hline & $\mathrm{T} 2$ & $319.9 \pm 60.9$ & $81.6 \pm 7.7$ & $6.5 \pm 0.9$ & $9.2 \pm 0.1$ \\
\hline \multirow{2}{*}{28} & $\mathrm{~T} 1$ & $229.0 \pm 45.9$ & $78.6 \pm 2.4$ & $6.9 \pm 0.6$ & $9.4 \pm 0.3$ \\
\hline & $\mathrm{T} 2$ & $242.8 \pm 60.5$ & $75.8 \pm 10.7$ & $6.6 \pm 0.8$ & $9.2 \pm 0.2$ \\
\hline \multirow{2}{*}{30} & $\mathrm{~T} 1$ & $194.7 \pm 60.4$ & $78.7 \pm 4.1$ & $6.5 \pm 1.0$ & $9.2 \pm 0.3$ \\
\hline & $\mathrm{T} 2$ & $216.8 \pm 29.3$ & $74.7 \pm 7.9$ & $6.9 \pm 0.7$ & $9.4 \pm 0.3$ \\
\hline
\end{tabular}

Mean \pm S.D.

a,b Means with different superscripts in the same column differ significantly $(\mathrm{p}<0.05)$.

1) T1: ad libitum feeding of concentrates; T2: restricted feeding of concentrates.

2) IGF- I : insulin like growth factor- I ; ${ }^{3)}$ Glu: glucose; ${ }^{4)} \mathrm{IP}$ : inorganic phosphorus; ${ }^{5)} \mathrm{Ca}$ : calcium.

한 수준이었고, 비록 품종은 다르지만, 권 등 (2001)이 홀스타인 수소 및 거세우의 혈중 IP 농도는 생후 2 3개월령에 $7.53 \sim 8.48 \mathrm{mg} / \mathrm{dl}$ 에서 20 개월령에 $7.08 \sim 7.30 \mathrm{mg} / \mathrm{dl}$ 로 감소했으며, 혈중 calcium 농도는 12개월령에 $11.03 \sim 11.08 \mathrm{mg} / \mathrm{dl}$ 에 서 20 개월령에 $8.83 \sim 9.28 \mathrm{mg} / \mathrm{dl}$ 로 감소했다는 보 고와도 유사한 경향을 보였다. 따라서 본 시험 에서도 골격형성과 밀접한 관련이 있는 혈중 
Table 6. Effects of ad libitum and restricted feeding of concentrates on WBC, RBC, $\mathrm{Hb}$ and HCT values in Hanwoo steers

\begin{tabular}{|c|c|c|c|c|c|}
\hline Age, mo & Treatment $^{1)}$ & $\mathrm{WBC}^{2}\left(10^{3} / \mathrm{mm}^{3}\right)$ & $\operatorname{RBC}^{3}\left(10^{3} / \mathrm{mm}^{3}\right)$ & $\mathrm{Hb}^{4}(\mathrm{~g} / \mathrm{dl})$ & $\mathrm{HCT}^{5)}(\%)$ \\
\hline 2 & - & $13.0 \pm 2.5$ & $10,657.3 \pm 2,434.4$ & $12.7 \pm 1.8$ & $30.3 \pm 3.5$ \\
\hline 4 & - & $10.2 \pm 2.5$ & $8,952.5 \pm 2,024.0$ & $12.3 \pm 1.0$ & $30.5 \pm 3.7$ \\
\hline 6 & - & $10.6 \pm 5.3$ & $8,193.8 \pm 2,123.6$ & $12.7 \pm 0.9$ & $30.2 \pm 5.4$ \\
\hline \multirow{2}{*}{8} & $\mathrm{~T} 1$ & $9.6 \pm 3.9$ & $8,494.0 \pm 592.0^{b}$ & $12.8 \pm 0.5$ & $33.7 \pm 3.4$ \\
\hline & $\mathrm{T} 2$ & $9.3 \pm 2.5$ & $10,217.0 \pm 1,437.6^{\mathrm{a}}$ & $13.5 \pm 1.2$ & $34.7 \pm 3.2$ \\
\hline \multirow{2}{*}{10} & $\mathrm{~T} 1$ & $8.5 \pm 1.1$ & $9,140.1 \pm 530.7^{b}$ & $15.0 \pm 1.3$ & $35.4 \pm 2.6$ \\
\hline & $\mathrm{T} 2$ & $8.7 \pm 1.8$ & $10,711.7 \pm 1,609.7^{\mathrm{a}}$ & $14.2 \pm 1.8$ & $36.3 \pm 4.9$ \\
\hline \multirow{2}{*}{12} & $\mathrm{~T} 1$ & $5.4 \pm 0.3^{b}$ & $8,335.0 \pm 1,050.1$ & $13.9 \pm 0.1$ & $33.8 \pm 2.1$ \\
\hline & $\mathrm{T} 2$ & $8.7 \pm 2.6^{\mathrm{a}}$ & $9,770.0 \pm 1,754.2$ & $13.1 \pm 1.5$ & $32.4 \pm 3.4$ \\
\hline \multirow{2}{*}{14} & $\mathrm{~T} 1$ & $7.0 \pm 1.3$ & $9,965.0 \pm 308.9$ & $14.5 \pm 0.5$ & $41.1 \pm 1.4$ \\
\hline & $\mathrm{T} 2$ & $8.5 \pm 2.9$ & $9,826.2 \pm 1,055.0$ & $14.8 \pm 1.6$ & $42.5 \pm 6.2$ \\
\hline \multirow{2}{*}{16} & $\mathrm{~T} 1$ & $4.9 \pm 0.8^{b}$ & $9,615.1 \pm 1,053.3$ & $14.8 \pm 1.2$ & $44.8 \pm 3.0$ \\
\hline & $\mathrm{T} 2$ & $6.5 \pm 1.7^{\mathrm{a}}$ & $9,543.1 \pm 997.1$ & $15.2 \pm 1.3$ & $45.5 \pm 3.5$ \\
\hline \multirow{2}{*}{18} & $\mathrm{~T} 1$ & $3.7 \pm 0.1$ & $9,450.0 \pm 400.0$ & $13.7 \pm 0.8$ & $41.3 \pm 1.6$ \\
\hline & $\mathrm{T} 2$ & $5.9 \pm 2.9$ & $9,444.4 \pm 1,614.4$ & $14.4 \pm 2.5$ & $43.1 \pm 7.9$ \\
\hline \multirow{2}{*}{20} & $\mathrm{~T} 1$ & $5.2 \pm 0.1$ & $10,263.3 \pm 699.5$ & $15.8 \pm 0.8$ & $45.5 \pm 4.1$ \\
\hline & $\mathrm{T} 2$ & $6.2 \pm 1.6$ & $8,931.7 \pm 1,028.2$ & $15.4 \pm 0.6$ & $39.6 \pm 2.8$ \\
\hline \multirow{2}{*}{22} & $\mathrm{~T} 1$ & $10.5 \pm 1.7^{\mathrm{a}}$ & $9,960.0 \pm 976.0^{\mathrm{a}}$ & $17.3 \pm 1.4^{\mathrm{a}}$ & $45.0 \pm 1.0^{\mathrm{a}}$ \\
\hline & $\mathrm{T} 2$ & $8.4 \pm 1.2^{\mathrm{b}}$ & $8,299.0 \pm 756.8^{b}$ & $14.0 \pm 0.9^{\mathrm{b}}$ & $40.7 \pm 3.0^{\mathrm{b}}$ \\
\hline \multirow{2}{*}{24} & $\mathrm{~T} 1$ & $10.3 \pm 1.4$ & $8,782.3 \pm 120.7$ & $13.0 \pm 0.3$ & $40.6 \pm 3.4$ \\
\hline & $\mathrm{T} 2$ & $9.2 \pm 1.2$ & $8,515.8 \pm 869.1$ & $13.6 \pm 1.2$ & $40.4 \pm 3.5$ \\
\hline \multirow{2}{*}{26} & $\mathrm{~T} 1$ & $9.0 \pm 1.1$ & $8,745.7 \pm \quad 779.3$ & $14.0 \pm 1.0$ & $39.3 \pm 4.0$ \\
\hline & $\mathrm{T} 2$ & $8.0 \pm 2.6$ & $8,551.7 \pm 715.0$ & $15.1 \pm 0.5$ & $36.4 \pm 3.7$ \\
\hline \multirow{2}{*}{28} & $\mathrm{~T} 1$ & $10.5 \pm 4.6$ & $8,120.0 \pm 316.9$ & $14.5 \pm 0.4$ & $41.2 \pm 2.2$ \\
\hline & $\mathrm{T} 2$ & $11.6 \pm 3.2$ & $8,330.0 \pm 774.8$ & $14.6 \pm 1.4$ & $39.8 \pm 3.8$ \\
\hline \multirow{2}{*}{30} & $\mathrm{~T} 1$ & $9.8 \pm 2.3$ & $8,236.3 \pm 813.7$ & $14.7 \pm 1.4$ & $39.8 \pm 4.3$ \\
\hline & $\mathrm{T} 2$ & $12.1 \pm 3.0$ & $7,675.0 \pm 965.7$ & $13.7 \pm 1.5$ & $36.4 \pm 3.9$ \\
\hline
\end{tabular}

Mean \pm S.D.

a,b Means with different superscripts in the same column differ significantly $(\mathrm{p}<0.05)$.

1) T1: ad libitum feeding of concentrates; T2: restricted feeding of concentrates.

2) WBC: white blood cell; ${ }^{3)} \mathrm{RBC}$ : red blood cell; ${ }^{4)} \mathrm{Hb}$ : hemoglobin; ${ }^{5)} \mathrm{HCT}$ : hematocrit.

IP 및 calcium 농도 결과를 통해 간접적으로 육 성기 및 비육전기 동안 제한급여에 따른 거세 우의 골격성장의 차이가 없었을 것으로 판단된 다(Andersen과 Ingvartsen, 1984; Murphy 등, 1994b).
그러나 거세한우 산육생리 변화와 혈중대사물 질과의 관계에 대해서는 추후 더 많은 연구가 필요할 것으로 사료된다. 
Table 7. Effects of ad libitum and restricted feeding of concentrates on $\mathrm{MCV}, \mathrm{MCH}$ and $\mathrm{MCHC}$ values in Hanwoo steers

\begin{tabular}{|c|c|c|c|c|}
\hline Age, mo & Treatment $^{1)}$ & $\mathrm{MCV}^{2}\left(\mathrm{u}^{3}\right)$ & $\mathrm{MCH}^{3)}(\mathrm{pg})$ & $\mathrm{MCHC}^{4}(\%)$ \\
\hline 2 & -- & $30.0 \pm 7.5$ & $10.4 \pm 1.5$ & $41.9 \pm 1.1$ \\
\hline 4 & -- & $37.1 \pm 5.3$ & $14.9 \pm 2.2$ & $40.6 \pm 2.9$ \\
\hline 6 & -- & $37.1 \pm 3.1$ & $16.5 \pm 3.2$ & $41.2 \pm 4.8$ \\
\hline \multirow{2}{*}{8} & $\mathrm{~T} 1$ & $39.8 \pm 2.3^{\mathrm{a}}$ & $14.9 \pm 0.3^{\mathrm{a}}$ & $37.6 \pm 1.7$ \\
\hline & $\mathrm{T} 2$ & $34.4 \pm 4.1^{\mathrm{b}}$ & $13.4 \pm 1.2^{\mathrm{b}}$ & $38.9 \pm 1.7$ \\
\hline \multirow{2}{*}{10} & $\mathrm{~T} 1$ & $39.7 \pm 2.6^{\mathrm{a}}$ & $14.8 \pm 0.9^{\mathrm{a}}$ & $36.5 \pm 1.8^{b}$ \\
\hline & $\mathrm{T} 2$ & $34.2 \pm 3.9^{b}$ & $13.4 \pm 1.3^{b}$ & $39.2 \pm 1.5^{\mathrm{a}}$ \\
\hline \multirow{2}{*}{12} & $\mathrm{~T} 1$ & $41.3 \pm 2.8^{\mathrm{a}}$ & $14.8 \pm 0.1^{\mathrm{a}}$ & $34.7 \pm 0.1^{\mathrm{b}}$ \\
\hline & $\mathrm{T} 2$ & $33.8 \pm 4.6^{\mathrm{b}}$ & $13.7 \pm 1.8^{\mathrm{b}}$ & $39.6 \pm 3.2^{\mathrm{a}}$ \\
\hline \multirow{2}{*}{14} & $\mathrm{~T} 1$ & $41.3 \pm 2.4$ & $14.5 \pm 0.7$ & $35.2 \pm 1.0$ \\
\hline & $\mathrm{T} 2$ & $43.3 \pm 4.6$ & $15.1 \pm 0.9$ & $35.0 \pm 2.0$ \\
\hline \multirow{2}{*}{16} & $\mathrm{~T} 1$ & $45.6 \pm 3.4$ & $14.9 \pm 1.6$ & $33.6 \pm 1.3$ \\
\hline & $\mathrm{T} 2$ & $48.0 \pm 4.7$ & $16.1 \pm 1.6$ & $33.4 \pm 1.1$ \\
\hline \multirow{2}{*}{18} & $\mathrm{~T} 1$ & $43.8 \pm 0.7$ & $14.5 \pm 0.6$ & $33.2 \pm 0.6$ \\
\hline & $\mathrm{T} 2$ & $45.6 \pm 2.4$ & $15.3 \pm 0.8$ & $33.5 \pm 0.9$ \\
\hline \multirow{2}{*}{20} & $\mathrm{~T} 1$ & $44.4 \pm 2.2$ & $15.5 \pm 1.8$ & $35.1 \pm 5.0$ \\
\hline & $\mathrm{T} 2$ & $44.5 \pm 2.4$ & $17.5 \pm 1.8$ & $39.1 \pm 2.0$ \\
\hline \multirow{2}{*}{22} & $\mathrm{~T} 1$ & $46.1 \pm 3.7$ & $16.3 \pm 1.4$ & $35.5 \pm 0.8^{\mathrm{a}}$ \\
\hline & $\mathrm{T} 2$ & $49.2 \pm 2.5$ & $16.9 \pm 1.0$ & $34.3 \pm 0.8^{b}$ \\
\hline \multirow{2}{*}{24} & $\mathrm{~T} 1$ & $46.5 \pm 4.0$ & $16.0 \pm 0.7$ & $32.3 \pm 3.0$ \\
\hline & $\mathrm{T} 2$ & $47.7 \pm 3.5$ & $16.1 \pm 1.5$ & $33.7 \pm 0.9$ \\
\hline \multirow{2}{*}{26} & $\mathrm{~T} 1$ & $44.9 \pm 1.8$ & $16.1 \pm 0.6$ & $35.8 \pm 1.5$ \\
\hline & $\mathrm{T} 2$ & $42.6 \pm 2.2$ & $17.4 \pm 1.7$ & $41.6 \pm 4.7$ \\
\hline \multirow{2}{*}{28} & $\mathrm{~T} 1$ & $50.7 \pm 2.9$ & $17.8 \pm 0.8$ & $35.2 \pm 1.4$ \\
\hline & $\mathrm{T} 2$ & $47.9 \pm 3.2$ & $17.6 \pm 1.0$ & $36.7 \pm 1.1$ \\
\hline \multirow{2}{*}{30} & $\mathrm{~T} 1$ & $48.3 \pm 2.6$ & $17.9 \pm 1.1$ & $37.1 \pm 1.0$ \\
\hline & $\mathrm{T} 2$ & $47.7 \pm 3.9$ & $17.9 \pm 1.0$ & $37.6 \pm 1.7$ \\
\hline
\end{tabular}

Mean \pm S.D.

a,b Means with different superscripts in the same column differ significantly $(\mathrm{p}<0.05)$.

1) T1: ad libitum feeding group of concentrates; T2: restricted feeding group of concentrates.

${ }^{2)} \mathrm{MCV}$ : mean corpuscular volume; ${ }^{3)} \mathrm{MCH}$ : mean corpuscular hemoglobin;

${ }^{4)} \mathrm{MCHC}$ : mean corpuscular hemoglobin concentration.

3. 혈액상

육성기 및 비육전기 배합사료 제한급여가 한 우 거세우의 $\mathrm{WBC}, \mathrm{RBC}, \mathrm{Hb}$ 및 $\mathrm{HCT}$ 등 혈액
상 변화에 미치는 영향은 Table 6에서와 같다.

$\mathrm{WBC}, \mathrm{RBC}, \mathrm{Hb}, \mathrm{HCT}, \mathrm{MCV}, \mathrm{MCH}$ 등과 같 은 혈액상들은 항병력과 관련된 주요 혈액성분 으로서 가축질병의 진단, 치료 및 생리적 변화 
의 병적상태와 예후를 판단하는데 중요한 혈액 성분으로(조 등, 2001) 본 연구에서는 배합사료 의 제한 유무에 따른 영양상태와 생리상태 변 화를 조사하기 위해 이들 혈액상의 변화를 살 펴보았다. 생후 12 및 14 개월령의 $\mathrm{WBC}$ 는 $\mathrm{T} 1$ 구 에 비해 $\mathrm{T} 2$ 구에서 높게 나타났으나 $(\mathrm{p}<0.05), 22$ 개월령에는 $\mathrm{T} 2$ 구에서 $\mathrm{T} 1$ 구에 비해 낮았다 $(\mathrm{p}<0.05)$. 그러나 대부분의 월령에서 처리간의 $\mathrm{WBC}$ 는 차이를 보이지 않아 제한급여가 $\mathrm{WBC}$ 에 미치는 영향은 적은 것으로 판단된다. 일반 적으로 $\mathrm{WBC}$ 는 품종, 연령, 환경, 시간, 운동, 채식상태, 채혈부위 등에 따라 달라지는데(신 등, 1996), 본 시험에서 나타난 결과는 조 등 (2001)의 한우 거세우의 $7.38 \sim 8.38 \mathrm{~K} / \mu l$ 및 권 등(2001)의 Holstein 거세우에서 생후 2 30개월 령 $5.90 \sim 11.09 \times 10^{3} / \mathrm{mm}^{3}$ 의 범주내에 있었고, 안 등(2005)의 Holstein 착유우 저능력와 고능력 집 단의 $9.27 \sim 9.46 \times 10^{3} / \mu$ l이었다는 보고와도 유사 한 수준이었다. $\mathrm{RBC}$ 는 생후 8 10개월령에는 $\mathrm{T} 1$ 구에 비해 $\mathrm{T} 2$ 구에서 높게 나타났으나 $(\mathrm{p}<$ $0.05), 22$ 개월령에는 $\mathrm{T} 2$ 구에 비해 $\mathrm{T} 1$ 구에서 높 았다 $(\mathrm{p}<0.05)$. 한편 $\mathrm{T} 1$ 구 및 $\mathrm{T} 2$ 구의 $8 \sim 30$ 개월 령 평균 $\mathrm{RBC}$ 는 각각 $9,092.2$ 및 $9,151.4 \times 10^{3}$ / $\mathrm{mm}^{3}$ 으로 나타나 $\mathrm{RBC}$ 의 경우에도 $\mathrm{WBC}$ 와 마찬 가지로 대부분 월령에서 사료의 제한급여가 $\mathrm{RBC}$ 에 미치는 영향은 적은 것으로 사료된다. $\mathrm{Hb}$ 및 $\mathrm{HCT}$ 의 경우 생후 22개월령에서만 $\mathrm{T} 2$ 구 에 비해 $\mathrm{T} 1$ 구에서 높았을 뿐 $(\mathrm{p}<0.05)$ 대부분의 월령에서 처리간에 차이를 보이지 않았다. 따 라서 $\mathrm{T} 1$ 구 및 $\mathrm{T} 2$ 구의 8 30개월령의 평균 $\mathrm{Hb}$ 는 각각 14.5 와 $14.3 \mathrm{~g} / \mathrm{dl}$ 이었고, 처리에 관계없이 사료급여 방법 혹은 월령에 관계없이 상대적으 로 큰 변화 없이 일정한 값을 보였다. 또한 $\mathrm{T} 1$ 구 및 $\mathrm{T} 2$ 구의 8 30개월령 평균 $\mathrm{HCT}$ 는 각각 40.1 및 $39.0 \%$ 로 나타났으며, $\mathrm{Hb}$ 와 마찬가지로 사료급여 방법 혹은 월령에 관계없이 상대적으 로 일정한 경향을 보였다. 이와 같은 결과는 조 등(2001)의 한우 거세우에서 $\mathrm{Hb}$ 및 $\mathrm{HCT}$ 는 각각 $10.68 \sim 11.76 \mathrm{~g} / \mathrm{dl}$ 및 $31.47 \sim 36.37 \%$, 권 등 (2001)의 Holstein 거세우에서 각각 9.23 13.78 $\mathrm{g} / \mathrm{dl}$ 및 $23.35 \sim 37.45 \%$ 이었다는 보고에 비해 $\mathrm{Hb}$ 는 약간 높은 수준이었지만 HCT는 유사한 수
준이었다.

육성기 및 비육전기 배합사료 제한급여가 한 우 거세우의 $\mathrm{MCV}, \mathrm{MCH}$ 및 $\mathrm{MCHC}$ 의 변화에 미치는 영향은 Table 7에서와 같다.

$\mathrm{T} 1$ 구와 $\mathrm{T} 2$ 구의 생후 8,10 및 12 개월령의 $\mathrm{MCV}$ 는 각각 39.8 vs $34.4,39.7$ vs 34.2 및 41.3 vs $33.8 \mathrm{u}^{3}$ 이었고, $\mathrm{MCH}$ 는 각각 14.9 vs 13.4 , 14.8 vs 13.4 및 14.8 vs $13.7 \mathrm{pg}$ 이었다. 따라서 $\mathrm{MCV}$ 와 $\mathrm{MCH}$ 는 $\mathrm{T} 2$ 구에서 사료급여 형태가 자 유급여에서 제한급여로 바뀌는 육성기 일정기 간(생후 8 12개월령) $\mathrm{T} 1$ 구에 비해 유의적으로 낮아지는 것으로 나타났으나 $(\mathrm{p}<0.05), 12$ 개월령 이후에는 $\mathrm{T} 1$ 구 수준으로 회복하여 처리간에 차 이가 없었다. 한편, $\mathrm{T} 1$ 구와 $\mathrm{T} 2$ 구의 생후 8,10 및 12 개월령의 $\mathrm{MCHC}$ 는 각각 37.6 vs 38.9 , 36.5 vs 39.2 및 34.7 vs $39.6 \%$ 로 나타나 $\mathrm{MCV}$ 및 $\mathrm{MCH}$ 와는 반대로 $\mathrm{T} 2$ 구에서 사료급여 형태 가 자유급여에서 제한급여로 바뀜에 따라 일정 기간 동안 $\mathrm{T} 1$ 구에 비해 많았지만 $(\mathrm{p}<0.05), 12$ 개 월령 이후에는 $\mathrm{T} 1$ 구와 $\mathrm{T} 2$ 구간의 $\mathrm{MCHC}$ 의 차이 는 없었다. 이와 같은 결과는 비록 축종은 다 르지만 권 등(2001)이 생후 2 20개월령 Holstein 거세우의 $\mathrm{MCV}, \mathrm{MCH}$ 및 $\mathrm{MCHC}$ 는 각각 36.48 $41.85 \mathrm{u}^{3}, 14.55 \sim 15.43 \mathrm{pg}$ 및 $36.80 \sim 40.00 \%$ 이었다 는 보고와 유사한 수준이었지만, 조 등(2001)이 생후 4 10개월령 한우 거세우의 $\mathrm{MCV}, \mathrm{MCH}$ 및 $\mathrm{MCHC}$ 는 각각 $30.11 \sim 31.68 \mathrm{f} \ell, 10.21 \sim 10.84$ $\mathrm{pg}$ 및 $32.93 \sim 34.90 \mathrm{~g} / \mathrm{dl}$ 이었다는 보고에 비해서 는 높은 수준인 것으로 나타났는데 이는 월령 및 시험기간의 차이에서 비롯된 것으로 판단된 다.

\section{IV. 요 약}

본 연구는 한우 거세우 258 두를 이용하여 배 합사료 자유급여와 제한급여에 따른 증체량, 사료 섭취량, 혈중대사물질의 농도 및 혈액상 에 대한 변화를 조사하기 위해 실시하였다. 시 험구 배치는 전기간 배합사료 자유급여구(T1) 와 생후 6 18개월령 배합사료 제한급여구(T2) 2 처리로 하였으며, 배합사료의 제한급여 수준 은 육성기에는 체중의 $1.2 \sim 1.5 \%$ 그리고 비육전 
기에는 체중의 $1.7 \sim 1.8 \%$ 수준으로 하였다. 생후 10 14개월령의 일당증체량은 T2구에 비해 T1 구에서 많았으나 $(\mathrm{p}<0.05), 20 \sim 24$ 개월에는 $\mathrm{T} 1$ 구 에 비해 $\mathrm{T} 2$ 구의 일당증체량이 많았다 $(\mathrm{p}<0.05)$. 총 건물섭취량의 경우 생후 10,12 및 16 개월 령에는 $\mathrm{T} 1$ 구에서, 22개월령에는 $\mathrm{T} 2$ 구에서 상대 적으로 높은 결과 $(\mathrm{p}<0.05)$ 를 보였을 뿐 여타 월 령에서는 차이가 없었다. 사료요구율은 20 30 개월령까지 $\mathrm{T} 1$ 구에 비해 $\mathrm{T} 2$ 구에서 유의적으로 감소하였다 $(\mathrm{p}<0.05)$. 생후 $12,14,16$ 및 18 개월 령의 혈중 albumin 농도는 $\mathrm{T} 1$ 구에 비해 $\mathrm{T} 2$ 구에 서 높았으나 $(\mathrm{p}<0.05), 12 \sim 18$ 개월령을 제외한 다 른 월령에서는 처리간의 농도 차이는 없었다. 생후 14 및 16 개월령의 혈중 triglyceride 농도는 $\mathrm{T} 2$ 구에 비해 $\mathrm{T} 1$ 구에서 높았으며 $(\mathrm{p}<0.05), 8,10$, 16 및 22개월령의 혈중 IP 농도는 T1구에 비해 $\mathrm{T} 2$ 구에서 높았다 $(\mathrm{p}<0.05)$. 생후 8 12개월령의 $\mathrm{MCV}$ 와 $\mathrm{MCH}$ 는 $\mathrm{T} 1$ 구에 비해 $\mathrm{T} 2$ 구에서 낮았으 나 $(\mathrm{p}<0.05), 10 \sim 12$ 개월 $\mathrm{MCHC}$ 는 $\mathrm{T} 1$ 구에 비해 $\mathrm{T} 2$ 구에서 높았다 $(\mathrm{p}<0.05)$. 이상의 연구결과를 종합해 볼 때 육성기 배합사료 제한급여는 비 육기 증체에 대한 부의 영향이 없고 비육후기 사료요구율도 감소시키기 때문에 육성기의 배 합사료 제한급여가 바람직하다.

\section{$\mathrm{V}$. 인 용 문 헌}

1. Andersen, H. R. and Ingvartsen, K. L. 1984. The influence of energy level, weight at slaughter and castration on growth and feed efficiency in cattle. Livestock Prod. Sci. 11:559-569.

2. AOAC. 1995. Official Methods of Analysis. 16th Ed. Association of Official Analytical Chemists, Washington D.C., U.S.A.

3. Arave, C. W., Miller, R. H. and Lamb, R. C. 1975. Genetic and environmental effects on serum cholesterol of dairy cattle of various ages. J. Dairy Sci. 58:3-11.

4. Daughaday, E. and Rotwein, P. 1989. Insulin like growth factors I and II. Peptide, messenger ribonucleic acid and gene structures, serum and tissue concentrations. Endocrin. Rev. 10:68-91.

5. Dolezal, H. G., Smith, G. C., Savell, J. W. and
Carpenter, Z. L. 1982. Effect of time-on-feed on the palatability of rib steaks from steers and heifers. J. Food Sci. 47:368-379.

6. Galbraith, H., Dempster, D. G. and Miller, T. B. 1978. A note on the effect of castration on the growth performance and concentrations of some blood metabolites and hormones in British Fresian male cattle. Anim. Prod. 26:339-342.

7. Hayden, J. M., Williams, J. E. and Collier, R. J. 1993. Plasma growth hormone, insulin-like growth factor, insulin, and thyroid hormone association with body protein and fat accretion in steers undergoing compensatory gain after dietary energy restriction. J. Anim. Sci. 71:3327-3338.

8. Hermesmeyer, G. N., Berger, L. L., Nash, T. G. and Brandt, R. T. 2000. Effects of energy intake, implantation, and subcutaneous fat end point on feedlot steer performance and carcass composition. J. Anim. Sci. 78:825-831.

9. Hermesmeyer, G. N., Berger, L. L., Merchen, N. R. and Nash, T. G. 2002. Effects of restricted and ad libitum intake of diets containing wheat middlings on site and extent of digestion in steers. J. Anim. Sci. 80:812-817.

10. Hicks, R. B., Owens, F. N., Gill, D. R., Martin, J. J. and Strasia, C. A. 1990. Effects of controlled feed intake on performance and carcass characteristics of feedlot steers and heifers. J. Anim. Sci. 68:233-244.

11. Hornick, J. L., Van Eenaeme, C., Diez, M., Minet, V. and Istasse, L. 1998. Different periods of feed restriction before compensatory growth in Belgian Blue bulls: II. Plasma Metabolites and Hormones. J. Amin. Sci. 76:260-271.

12. Huntington, G. B., Zetina, E. J., Whitt, J. M. and Potts, W. 1996. Effects of dietary concentrate level on nutrient absorption, liver metabolism, and urea kinetics of beef steers fed isonitrogenous and isoenergetic diets. J. Anim Sci. 74:908-916.

13. Loerch, S. C. 1990. Effects of feeding growing cattle high-concentrate diets at a restricted intake on feedlot performance. J. Anim. Sci. 68:30863095.

14. Loerch, S. C. and Fluharty, F. L. 1998. Effects of programming intake on performance and carcass characteristics of feedlot cattle. J. Anim. Sci. 
76:371-377.

15. Murphy, T. A. and Loerch, S. C. 1994 . Restricted feeding of growing steers on performance, carcass characteristics, and composition. J. Anim. Sci. 72: 2497-2507.

16. Murphy, T. A., Fluharty, F. L. and Loerch, S. C. 1994a. The influence of intake level and corn processing on digestibility and ruminal metabolism in steers fed all-concentrate diets. J. Anim. Sci. 72:1608-1615.

17. Murphy, T. A., Loerch, S. C. and Dehority, B. A. 1994b. The influence of restricted feeding on site and extent of digestion and flow on nitrogenous compounds to the duodenum in steers. J. Anim. Sci. 72:2487-2496.

18. SAS. 1999. SAS/STAT Software for PC. Release 6.11, SAS Institute, Cary, NC, U.S.A.

19. Ting, S. T. L., Earley, B. and Crowe, M. A. 2003. Effect of repeated ketoprofen administration during surgical castration of bulls on cortisol, immunological function, feed intake, growth, and behavior. J. Anim. Sci. 81:1253-1264.

20. Winger, Q. A., De los Rios, P., Han, V. K., Armstrong, D. T., Hill, D. J. and Watson, A. J. 1997. Bovine oviductal and embryonic insulin-like growth factor binding proteins: possible regulators of "embryotrophic" insulin-like growth factor circuits. Biol. Reprod. 56:1415-1423.

21. 권응기, 김현섭, 남기택, 윤상기, 김종복, 홍병주. 2001. Holstein 수소와 거세우 및 Zeranol 투여 거세우의 성장단계별 혈액상과 혈청대사물질 및 호르몬 농도 변화. 동물자원과학회지. 43(4):515524 .
22. 길준민. 1999. 한우 고급육 생산을 위한 맥주박 발효사료와 분쇄대두 급여 효과. 강원대학교 석 사학위논문.

23. 농림부. 2004. 농림부고시 제2004-66호 축산물등 급판정세부기준.

24. 백봉현, 김용곤, 신기준, 이근상, 김강식. 1989. 한우의 수소 거세 및 암소 육성비육시 육생산성 과 육질 및 사료이용성에 관한 연구. 농시논문집 (축산편). 31(4):1-8.

25. 신종서, 정준, 여인서, 김종복, 장병선, 홍병주. 1996. 재조합 성장호르몬 투여수준이 홀스타인 및 한우 비육우의 혈중 대사물질, 도체형질 및 도체구성에 미치는 영향. 한영사지. 20(5):473486.

26. 안병석, 권응기, 서국현, 이현준, 박병기. 2005. 젖소의 고능력우와 저능력우간의 우유 성분 및 혈중 대사물질 특성 비교. 동물자원과학회지. 47(1):11-18.

27. 임광철. 2001. 알코올 발효사료의 한우 반추위내 영양대사에 관한 연구. 강원대학교 박사학위논 문.

28. 조병대, 이근상, 나기준, 백봉현, 김형철, 홍성구, 김용곤, 이병석. 1992. 한우의 산육특성과 양질 쇠고기 생산기술 개발 연구. 축산시험장 연구보 고서.

29. 조원모, 백봉현, 강수원, 김준식, 김용국. 2001. 거세한우에 있어 점토광물질 첨가 급여가 발육 및 면역기능에 미치는 영향. 동물자원과학회지. 43(2):203-210.

30. 홍성구. 1996. 한우의 육질개선을 위한 비육기술 개발에 관한 연구. 충북대학교 박사학위논문.

(접수일자 : 2005. 4. 28. / 채택일자 : 2005. 10. 5.) 